\title{
DIFFERENCES IN COMPETITIVE ABILITY AMONG RACES OF Colletotrichum graminicola IN MIXTURES
}

\author{
CARLOS R. CASELA, ALEXANDRE S. FERREIRA \& FREDOLINO G. SANTOS
}

Embrapa Milho e Sorgo, Cx. Postal 151, CEP 35701-970, Sete Lagoas, MG, fax 31 779-1088, e-mail: casela@cnpms.embrapa.br

(Accepted for publication in 16/04/2001)

Corresponding author: Carlos R. Casela

CASELA, C.R., FERREIRA, A.S. \& SANTOS, F.G. Differences in competitive ability among races of Colletotrichum graminicola in mixtures. Fitopatologia Brasileira 26:217-219. 2001.

\begin{abstract}
Mixtures of races of Colletotrichum graminicola, causing sorghum (Sorghum bicolor) anthracnose and differing in their virulence range, were inoculated for five and six generations on the susceptible sorghum cultivar BR009 (Tx623), in two experiments in a greenhouse. In each generation a sample of 50 single spore isolates was obtained and inoculated on a standard differential set to determine the

proportion of each race in the mixture. Isolates of the race $30 \mathrm{~A}$, with the narrowest virulence range, predominated over isolates of the more complex races $31 \mathrm{~B}, 31 \mathrm{C}$ and $31 \mathrm{E}$ indicating the existence of differences in the survival ability among races of this pathogen.

Key words: Colletotrichum graminicola, virulence, fitness, Sorghum bicolor, anthracnose.
\end{abstract}

\section{RESUMO}

\section{Diferenças na capacidade competitiva entre raças de Colletotrichum graminicola em misturas}

Misturas de raças de Colletotrichum graminicola, o agente causal da antracnose do sorgo (Sorghum bicolor), com diferentes graus de complexidade quanto à virulência, foram inoculadas por cinco e seis gerações, na cultivar suscetível BR009 (Tx623) em dois experimentos conduzidos em casa de vegetação. Em cada geração, foi obtida uma amostra de 50 isolados monospóricos que foi inoculada em uma série diferencial padrão, para se verificar a proporção de cada raça na mistura. Predominaram os isolados da raça 30A, com menor grau de complexidade, em relação aos isolados das raças mais complexas 31B, 31C e 31E, indicando a existência de diferenças entre raças deste patógeno quanto à sua capacidade competitiva.
Sorghum anthracnose caused by Colletotrichum graminicola (Ces.) Wils. has been a major problem of sorghum [Sorghum bicolor (L.) Moench] in Brazil. The pathogen reduces yield of susceptible sorghum cultivars particularly under warm and humid environmental conditions (Ali et al., 1987). Colletotrichum graminicola is a highly variable organism (Cardwell et al., 1989, Pande et al., 1991). Races of $C$. graminicola in Brazil have been characterized according to differential interactions with a set of nine sorghum genotypes (Casela \& Ferreira, 1987). In this system races are separated into eight main groups designated by the letters $\mathrm{A}$ to $\mathrm{H}$, based on the reaction of cultivars BR008 (Redlan), BR005 (SC326-6), SC283, and BR009 (Tx623). Recent surveys indicate the predominance of race group A (virulent to BR009) over the race groups B (virulent to BR008 and BR009), C (virulent to BR005 and BR009), and E (virulent to BR008, BR005 and BR009), indicating a possible action of stabilizing selection against more virulent races of the pathogen in nature. According to Vanderplank (1868), races with unnecessary virulence tend to be eliminated by natural selection. Based on this hypothesis, this selection will stabilize the pathogen population and prevent the accumulation of virulence genes. If this phenomenon is present in the pathosystem S. bicolor - C. graminicola it will be possible to control anthracnose through the use of gene management strategies such as gene rotation, cultivar mixtures, and multigene cultivars.

This study was undertaken to evaluate differences in competitive ability of races of $C$. graminicola, with different levels of virulence, in mixtures on a susceptible cultivar.

Cultures of C. graminicola used in this study were collected in Sete Lagoas and maintained in oat meal agar (OMA). Single spore isolates obtained from original cultures were identified as races of $C$. graminicola by their virulence pattern on a differential set of nine cultivars (Casela \& Ferreira, 1987). Isolates of the races 30A, 31B, 31C, and 31E, were selected based on their ability to cause infection in the differential cultivars BR008 and BR005. The experiment was repeated twice, and different isolates of the same races were used in each study.

An initial mixture, in equal proportions, of the four races was used to inoculate 300 plants of the highly susceptible 
cultivar BR009 in the greenhouse. Inoculum was produced by flooding seven-day-old cultures, grown on OMA plates under continuous light at $25^{\circ} \mathrm{C}$, with distilled water. The cultures were scrapped with a scalpel, and the conidial suspension filtered through two layers of cheesecloth and the conidial concentration was adjusted to $10^{6}$ conidia/ml. Leaves of 30-day-old plants were inoculated with a hand sprayer. Plants were incubated for $18 \mathrm{~h}$ in the dark at $25-30{ }^{\circ} \mathrm{C}$ and at $100 \%$ relative humidity. Eight days after inoculation, infected leaves were cut into small pieces, washed three times in sterile distilled water and incubated for seven days to induce spore production. This spore population was considered to be the first generation of spores produced on the susceptible cultivar BR009. Inoculum for the subsequent generations was always obtained from the cultivar BR009 inoculated in the previous generation. This procedure was repeated for five generations in the first experiment and for six generations in the second experiment.

In each generation, a sample of 50 monoconidial isolates was obtained to measure the proportion of each race in the mixture. Isolates from each generation were inoculated on the standard differential set used for characterization of races of $C$. graminicola, using the previously described procedures for inoculum production, inoculation and incubation period. Differentials were planted in a split-plot arrangement using a randomized complete block design, with isolates as whole plots and sorghum genotypes as sub-plots. Due to the limitation of space in the greenhouse, isolates were inoculated in groups of five.

For the evaluation, plants were classified for infection type 12 days after inoculation, based on a 1-to-5 scale where

$1=$ presence of chlorotic flecks; $2=$ red spots on the leaf lamina; 3 = necrotic lesions, sometimes elongated, but no acervuli formed; $4=$ necrotic lesions formed with acervuli present in the center; and $5=$ necrotic lesions, sometimes coalescing with abundant formation of acervuli.

Disease symptoms were separated into two groups: $\mathrm{R}$ $=$ resistant (including infection types 1,2 , and 3 ) and $\mathrm{S}=$ susceptible (including infection types 4 and 5).

In both experiments, isolates of the race $30 \mathrm{~A}$, with the narrowest virulence range, predominated over isolates of the races $31 \mathrm{~B}, 31 \mathrm{C}$, and $31 \mathrm{E}$, after five and six generations on the susceptible cultivar BR009 (Figure 1). These results reflect differences in fitness among races of $C$. graminicola and are in agreement with field observations on race distribution in areas of predominance of anthracnose. Differences in the competitive ability among races of plant pathogens have been reported for several plant pathosystem (Thurston, 1961; Martens, 1973).

The predominance of the race $30 \mathrm{~A}$, the less virulent, and the lowest frequency of the race $31 \mathrm{E}$, with the highest number of unnecessary virulences, after five and six generations on the susceptible genotype BR009, indicated a possible influence of virulence on the survival ability of races of C. graminicola. Despite the similar results in both experiments, they can not be considered, however, as evidence

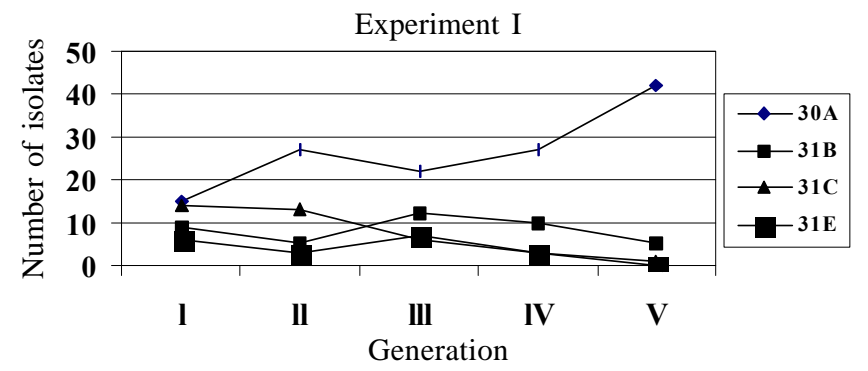

Experiment II

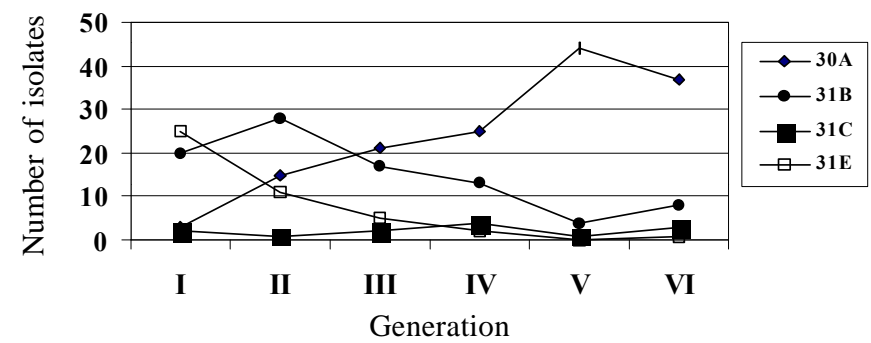

FIG. 1 - Changes in the composition of two mixtures of four races of Colletotrichum graminicola inoculated on the susceptible sorghum (Sorghum bicolor) cultivar BR009 over five (experiment I) and six (experiment II) generations.

of a negative relationship between unnecessary virulence and aggressiveness of races of $C$. graminicola as postulated by Vanderplank (1968). More extensive data from field and greenhouse experiments involving additional races of the pathogen, with different virulence ranges, and sorghum genotypes are necessary to confirm this relationship. Moreover, reduced fitness associated with a wider virulence range will not be enough to confirm this hypothesis. Analysis of F1 progenies of crosses between isolates of Erysiphe graminis D.C. f. sp. tritici E. Marchal, indicated that virulence segregated independently of reduced fitness (Bronson \& Ellingboe, 1986). Additionally, it is important to note that results on the survival ability of races of plant pathogens in mixtures varies greatly. Studies of Watson \& Singh (1952) with Puccinia graminis Pers. f. sp. tritici Eriks. \& Henn. and Leonard (1969), with P. graminis Pers. f. sp. avenae Eriks. $\&$ Henn, indicated a predominance of simple races in mixtures with complex races, whereas in those of Katsuya \& Green (1967) and Osoro \& Green (1976) with stem rust races, no clear relationship between survival ability and complexity could be established.

Despite such variable results, evaluation of the survival ability of $C$. graminicola, can be an important tool in breeding for disease resistance. As stressed by Brodny et al. (1988), early detection of the parasitic fitness in virulent races is a high priority in the development of resistance against variable pathogens as they may represent a serious threat to the cultivation of the crop. Information on the survival ability of races is also of fundamental importance in gene deployment strategies, to avoid the appearance of races of high parasitic 
Differences in competitive ability among races of Colletotrichum graminicola in mixtures

fitness in the population of virulent races, as observed with the race 15B in the United States (Nelson, 1972). Studies involving cultivar mixtures have already demonstrated the viability of this strategy to manage sorghum anthracnose (Guimarães et al., 1998). Gene rotation involving sorghum genotypes BR005 and BR008 has been evaluated by Embrapa Maize and Sorghum as another alternative strategy to manage this disease in Brazil.

\section{LITERATURE CITED}

ALI, M.E.K., WARREN, H.L., \& LATIN, R.X. Relationship between anthracnose leaf blight and losses in grain yield of sorghum. Plant Disease 71:803-805. 1987.

BRODNY, U., WAHL, I. \& ROTTEM, J. Factors conditioning dominance of races 276 of Puccinia coronata avenae on Avena sterilis populations in Israel. Phytopathology 78:135-139. 1988.

BRONSON, C.R. \& ELLINGBOE, A.H. The influence of four unnecessary genes for virulence on the fitness of Erysiphe graminis f. sp. tritici. Phytopathology 76:154158. 1986

CARDWELL, K.F., HEPPERLY, P.R. \& FREDERIKSEN, R.A. Pathotypes if Colletotrichum graminicola and seed transmission of sorghum anthracnose. Plant Disease 73:255-257. 1989.

CASELA, C.R. \& FERREIRA, A.S. Proposta para um sistema de classificação de raças de Colletotrichum graminicola, agente causal da antracnose em sorgo (Sorghum bicolor). Fitopatologia Brasileira 12:337-344. 1987.

GUIMARÃES, F.B., CASELA, C.R., SANTOS, F.G. \&
FERREIRA, A.S. Controle da antracnose do sorgo pelo uso de mistura de cultivares. Summa Phytopathologica 24:131-135. 1998.

KATSUYA, K., \& GREEN, G.J. Reproductive potentials of races $15 \mathrm{~B}$ and 56 of wheat stem rust. Can. J. Bot. 45:1077-1091. 1967.

LEONARD, K.J. Selection in heterogeneous populations of Puccinia graminis f. sp. avenae. Phytopathology 59:1851-1857. 1969.

MARTENS, J.W. Competitive ability of oat stem rust strains in mixtures. Canadian Journal of Botany 51: 2233 2236. 1973.

NELSON, R.R. Stabilizing racial populations of plant pathogens by use of resistance genes. J. Env. Qual. 1:220226. 1972.

OSORO, M.O. \& GREEN, G.J. Stabilizing selection in Puccinia graminis tritici in Canada. Canadian Journal of Botany 54:2204-2214. 1976.

PANDE, S., MUGHOGHO, L.K., BANDYOPADHYAY, R. \& KARUNAKAR, R.I. Variation in pathogenicity and cultural characteristics of sorghum isolates of Colletotrichum graminicola. Plant Disease 75:778-783. 1991.

THURSTON, H.D. The relative survival ability of races of Phytophthora infestans in mixtures. Phytopathology 51:748-755. 1961.

VANDERPLANK, J.E. Disease Resistance in Plants. Academic Press. New York. 1968. 206pp.

WATSON, I.A. \& SINGH, D. The future for rust resistant wheat in Australia. The journal of the Australian Institute of Agriculture Science 18:190-197. 1952. 